\title{
MARINE NEOGENE SAMPLES FROM AROUND TASMANIA: AN EXTENSION TO THE MIOCENE/PLIOCENE MARINE RECORD IN TASMANIA
}

\author{
by Patrick G. Quilty and Andrew Telfer \\ (with two tables, three text-figures and two plates)
}

\begin{abstract}
Quit.ty, P.G. \& Tel.FER, A., 1994 (30:vi): Marine Neogene Samples from around Tasmania: an extension to the Miocene/Pliocene marine record in Tasmania. Pap. Proc. R. Soc. Tasm. 128: 41-56. https://doi.org/10.26749/rstpp.128.41

ISSN 0080-4703. Australian Antarctic Division, Channel Highway, Kingsron, Tasmania, Australia 7050 (PGQ); Engineering and IV.:'ater Supply Department, Box 603, Mount Gambier, South Australia, Australia 5290 (AT).
\end{abstract}

\begin{abstract}
New Miocene and Quaternary foraminiferid faunas have been recovered from previously unrecorded localities onshore near Penguin and Strahan, and at nine offshore localities off northwestern, northeastern and southeastern Tasmania. Most Miocene benthic forms found in these samples are well known from other Tasmanian Tertiary sections but a few previously unreported taxa are recorded in Tasmania for the first time. Two samples from off northeastern Tasmania are Miocene. The sample from southeastern Tasmania is Early Miocene with Quaternary overlying it. Pebbles from Ocean Beach, north of Strahan, contain earliest Middle Miocene faunas. Other samples from off northeastern and northwestern Tasmania contain Quaternary faunas which probably reflect both periods of lower sea level and cool water and also periods of higher sea level and warmer water.

These samples extend the range of Miocene calcareous sediments much farther south on both west and east coasts of Tasmania. They also reinforce the pattern of Tasmanian Neogene sedimentation cycles (earliest Early Miocene, latest Early-earliest Middle Miocene, midLate Pliocene) identified previously.
\end{abstract}

Key Words:Neogene, Miocene, Quaternary, marine fauna, Tasmania, foraminifera.

\section{INTRODUCTION}

The biostratigraphy of Tasmanian Tertiary marine sediments was summarised by Quilty (1972), and the foraminiferid faunas were documented by Quilty $(1974,1977$ a, 1980a, 1982). Since then, fieldwork on Flinders Island, and accidental sediment recoveries during trawling by Tasmanian Sea Fisheries (then the Tasmanian Fisheries Development Authority, TFDA) have yielded foraminiferid bearing samples (Quilty 1985a, b). Further biostratigraphic data have been obtained from drilling for hydrocarbons. The most recent biostratigraphic summary that includes references to the Neogene is the relevant section of Burrett \& Martin (1989).

The aim of this paper is to record the foraminiferid faunas and interpret the environment of deposition of several new Tasmanian Neogene samples. A revised model of the Tasmanian marine environment during the Neogene will then be presented.

Unfortunately, conditions throughout the MioceneQuaternary in the waters around Tasmania generally were cool enough, with exceptions noted by Quilty (1972), that low-latitude, planktonic foraminiferid-based zonations such as those of Blow (1969) and Stainforth et al. (1975) are not readily applicable, and it is necessary to use both southeastern Australian benthic zonations, such as proposed by Carter (1958, 1964), Ludbrook \& Lindsay (1969), and also midlatitude, planktonic foraminiferid-based schemes such as those of Jenkins $(1971,1985)$ and Kennett \& Srinivasan (1983). These schemes do not provide the resolution of zones, as do the Blow/Stainforth schemes mentioned above, nor do they allow spot samples, such as available here, to be dated with the precision of samples from warmer water continuous sequences. Another feature is that some samples were deposited in waters shallow enough for the full diversity of planktonic foraminiferids in existence in the region not to be represented in the sediments.

\section{Samples and location}

Locations of the samples are shown in figure 1. Detailed coordinates, depth and University of Tasmania acquisition numbers are shown on table 1.

The sample from between Penguin and Ulverstone (UTGD76649, near sea level, below the Lonah Road, between Tea Tree Point and Penguin Point; fig. 2) was discovered late in 1986 by the Tasmanian Geological Survey (now Mineral Resources, Tasmania), during fieldwork related to the large landslip known as Grooms Slip. The features of the slip were reported initially by Balsille (1936). A very thin, fossiliferous horizon is present and consists of sandy, silty clay with approximately $30 \%$ shell material in small lenses. It comes from the base of the cliff section next to an adit located above the centre of the slip and on a level at, or slightly above, a wave cut bench. Sediments above the marine horizon appear to be nonmarine clayey sand and sand.

Several offshore samples (UTGD66532-536) were recovered by CSIRO in 1986, as an unexpected and unwanted benefit of trawling activities during fishery research cruises in the region, conducted on R/V Soela (Cruises SO3/86 and SO4/86). In mid-July 1992, one was collected accidentally in approximately $1000 \mathrm{~m}$ water depth from an area known locally as the St Helens Hills during fishing operations of FRV Southern Surveyor (Cruise SS3/92). The St Helens Hills is the local term applied to an area of water depth 580-1000 m lying about 45 nautical miles east of St Helens, a known Orange Roughy (Hoplostethus atlanticus Collett) fishing area with a rugged bottom. 

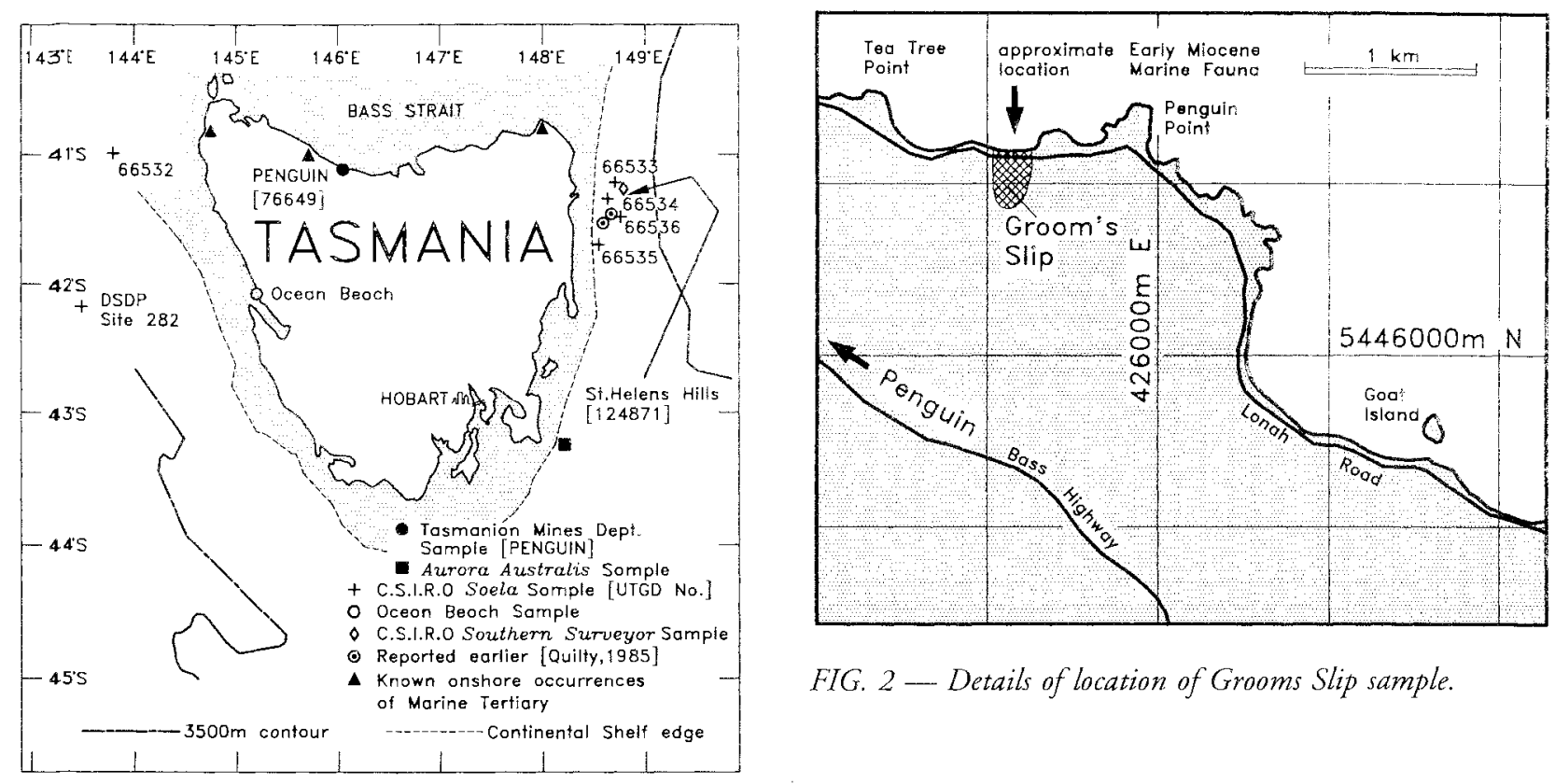

FIG. 2 - Details of location of Grooms Slip sample.

FIG. 1 - Locality map.

TABLE 1

Sample information

\begin{tabular}{|c|c|c|c|c|}
\hline Location & $\begin{array}{l}\text { UTGD } \\
\text { sample }\end{array}$ & Latitude & Longitude & $\begin{array}{l}\text { Depth } \\
(\mathrm{m})\end{array}$ \\
\hline \multicolumn{5}{|l|}{ Soela samples } \\
\hline \multicolumn{5}{|l|}{ Western Tasmania } \\
\hline S03/86 Station 31 & 66532 & $41^{\circ} 01^{\prime} \mathrm{S}$ & $143^{\circ} 51^{\prime} \mathrm{E}$ & 560 \\
\hline \multicolumn{5}{|l|}{ Eastern Tasmania } \\
\hline S04/86 Station 3 & 66535 & $41^{\circ} 42^{\prime} \mathrm{S}$ & $148^{\circ} 43^{\prime} \mathrm{E}$ & 1160 \\
\hline S04/86 Station 5 & 66536 & $41^{\circ} 38^{\prime} \mathrm{S}$ & $148^{\circ} 50^{\prime} \mathrm{E}$ & 940 \\
\hline S04/86 Station 7 & 66533 & $41^{\circ} 15.7^{\prime} \mathrm{S}$ & $148^{\circ} 46.9^{\prime} \mathrm{E}$ & 1136 \\
\hline S04/86 Station 8 & 66534 & $41^{\circ} 26^{\prime} S$ & $148^{\circ} 44.8^{\prime} \mathrm{E}$ & 870 \\
\hline St Helens Hills & 124871 & $41^{\circ} 14 \mathrm{~S}$ & $148^{\circ} 45.5^{\prime} \mathrm{E}$ & c. 1000 \\
\hline \multirow[t]{6}{*}{ Ocean Beach, Strahan } & 124886 & $42^{\circ} 07.5^{\prime} \mathrm{S}$ & $145^{\circ} 15.5 \mathrm{E}^{\prime}$ & 0 \\
\hline & 124887 & & & \\
\hline & 124888 & & & \\
\hline & 124889 & & & \\
\hline & 124890 & & & \\
\hline & 124891 & & & \\
\hline \multicolumn{5}{|l|}{ Aurora Australis sample } \\
\hline Southeastern Tasmania & 78185 & $43^{\circ} 15.53^{\prime} \mathrm{S}$ & $148^{\circ} 14.25^{\prime} \mathrm{E}$ & 810 \\
\hline North Coast, Penguin & & & & \\
\hline outcrop & 76649 & $41^{\circ} 37.2 \mathrm{~S}$ & $146^{\circ} 6.4^{\prime} \mathrm{E}$ & 0 \\
\hline
\end{tabular}


Samples collected from off northeastern Tasmania by CSIRO are from within a few nautical miles of the samples reported by Quilty (1985b).

The corc from offshore southeastern Tasmania was taken on 3 Jan uar 1993, during testing of gravity coring equipment stpplied by the Australian Geological Survey Organisation (AGSO), from RSV Aurora Australis under charter to the Australian Antarctic Division. The core is approximately $200 \mathrm{~mm}$ long, and has a diameter of $85 \mathrm{~mm}$. There is so mepoorly controlled bottom profiler information for this site.

The samples from Ocean Beach, $6 \mathrm{~km}$ north of Strahan, consist of six rounded beach pebbles, $40-60 \mathrm{~mm}$ in diameter, in which molusc fossils are abundant and clearly visible. They were collected early in 1993. Their source is not known but is likely to be nearby, probably offshore in waters less than $30 \mathrm{~m}$ deep. They probably have been brought to the beach by wave activity. They are much softer and less smoothed and rounded than other abundant beach pebbles of tough, silica rich Palaeozoic and Precambrian rocks, which seem to be brought to their position by longshore currents or reworked onto the beach from pebble horizons in nearby Quaternary sediments. The older material is probably redistributed from conglomerates in the Palacogene and Quaternary sediments that fill the Macquarie Harbour Graben (Baillie \& Corbett 1985). The Neogene calcareous pebbles are taken to be within a few kilometres of their source.

\section{Processing}

Material from most samples was soaked in water or Calgon solution to disaggregate. It was then washed over sieves, and the residue retained on sieves coarser than 125 microns was picked to yield the faunas recorded here. The sample from the Aurora Australis core was more indurated than the others, and some crushing was needed before routine processing. The samples from Ocean Beach, Strahan, and from the St Helens Hills were studied from thin sections, as they were too indurated for disaggregation.

\section{Sample repository}

Specimens of the rocks yielding the faunas are held in the collections of the Geology Department, University of Tasmania. Table 1 shows the relationship between the number of that specimen in the Geology Department collection and field numbers. Mounted foraminiferid specimens from each sample are held by the senior author. Figured specimens of foraminiferids are housed in the UTGD collections, and accession numbers for the figured specimens are given on the plate explanation. Geology Department (UTGD) numbers are used throughout this paper.

\section{FAUNAS, AGE AND PALAEOECOLOGY}

\section{Penguin-Grooms Slip}

\section{Lithology}

UTGD76649 is soft, friable, apparently nonbedded, poorly sorted, iron-stained, shelly marl that disaggregates readily.

\section{Age}

The diverse foraminiferid fauna from the single sample is very similar to that reported by Quilty (1972) from the lowest part of the Fossil Bluff section, $37 \mathrm{~km}$ to the northwest. Both sections occur within a few metres of modern sea level. Approximately 99\% of the fauna is of benthic species, which are dominated by "Valvulineria" kalimnensis (Parr), Elphidium spp. and several miliolid species, including Crenulostomina banksiQuilty. The species distribution is shown on table 2. Sherbornina cuneimarginata and Globorosalina scabricula (Chapman) are recorded for the first time in Tasmania. Planktonic species are uncommon, and only Globigerina brazieri Jenkins and $G$. connecta Jenkins have been identified from the sample. Other elements of the biota include wood fragments, bryozoans, cirripedes, gastropods, bivalves and rare fish otoliths.

Key benthic species for age determination in the Carter (1958) Faunal Unit scheme are Calcarina mackayi (Karrer), Planorbulinella inaequilateralis (Heron-Allen and Earland), Sherbornina cuneimarginata, Notorotalia howchini (Chapman, Parr and Collins) and Operculina victoriensis Chapman and Parr. P. inaequilateralis, although stated by Carter to appear in Faunal Unit 7, has been documented by Quilty (1982) from Faunal Unit 6 sediments at Fossil Bluff, Wynyard, where "Valvulineria" kalimnensis also is abundant and commonly the dominant species.

The fauna is typical of assemblages that can be correlated with Carter's (1958) Faunal Unit 6, which is earliest Miocene (approximately N5, Globoquadrina dehiscens praedehiscens$G$. dehiscens dehiscens Partial-range zone of Blow 1969: see figure 3, based on Abele, in Douglas \& Ferguson 1976).

\section{Palaeoenvironment}

Dominance (the proportion of the benthic fauna made up by the dominant species - Walton 1964, Quilty 1972) is $17 \%$, and Diversity (the number of species making up $95 \%$ of the benthic fauna) is 18 . These figures are characteristic of faunas from the deeper end of the 0-10 fathom field identified by Quilty (1972). Other elements of the biota noted above, however, suggest shallower water deposition and are a little at variance with the Dominance/Diversity figures. Dominance is lower and Diversicy higher than expected from interpretation based on other elements of the fauna. The evidence from planktonic percentage and macrofauna is consistent with deposition in a close inshore, protected environment within a few metres of sea level. 
TABLE 2

Distribution of foraminifera in the samples

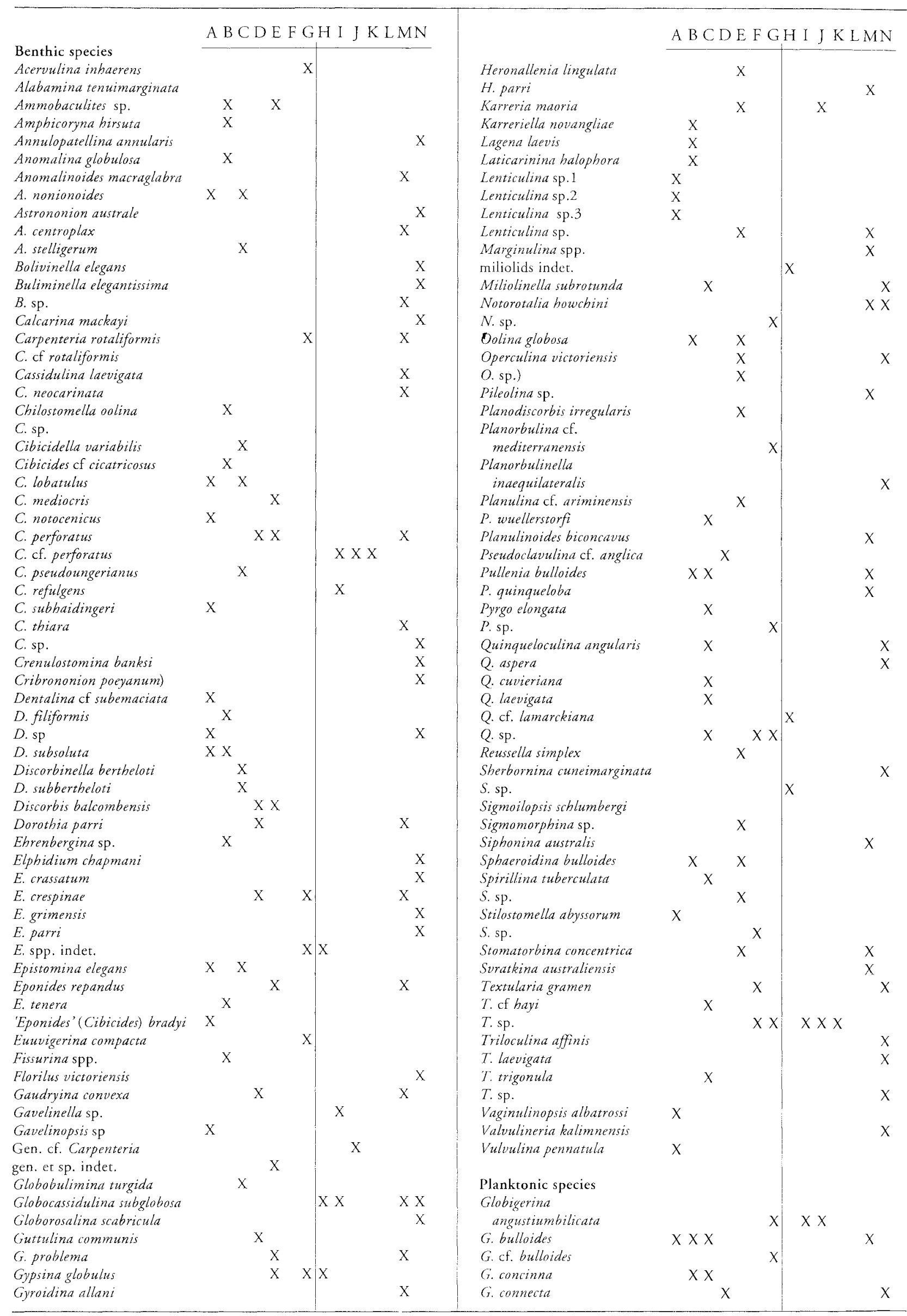


Table 2 cont.

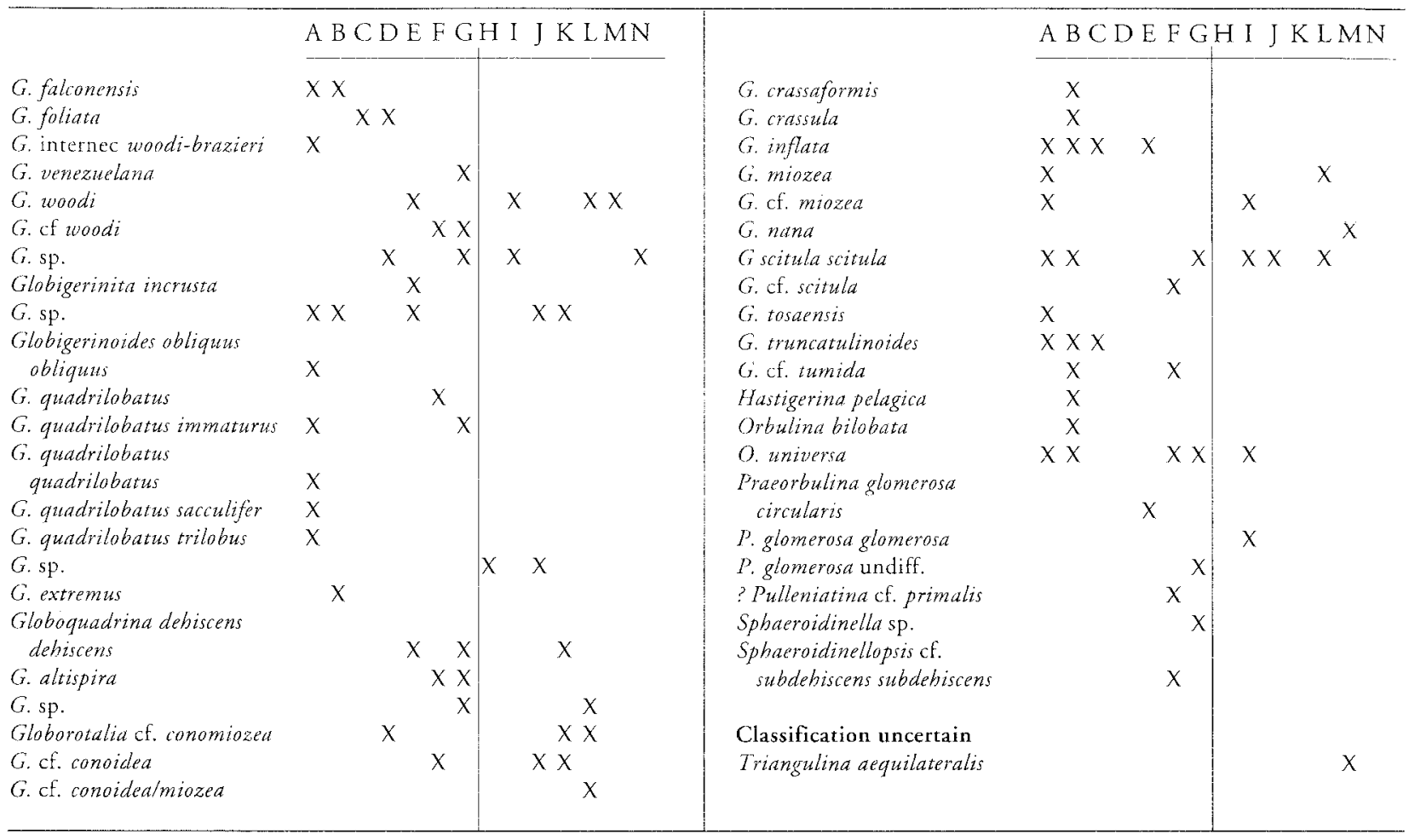

* Key to localities. (A-E) CSIRO samples, UTGD66532, UTGD66535, UTGD66536, UTGD66533 and UTGD66534 respectively; (F) St Helens Hills sample, UTGD124871; (G-L) Ocean Beach, Strahan, samples UTGD124886-91 respectively; (M) Aurora Australia sample, UTGD78185; (N) Penguin sample, UTGD76649.

\section{SAMPLES TRAWLED BY CSIRO}

\section{UTGD66532 — offshore northwestern Tasmania}

\section{Lithology}

Grey-green, nonbedded marl with minor bryozoan and mollusc content. When dried it is quite hard but disaggregates readily, producing very small residue coarser than 125 microns, with high proportion of clay and very well preserved foraminiferids, very dominantly planktonic.

\section{Age}

This is the sole CSIRO specimen from offshore northwestern Tasmania - from the West Tasmanian Shelf of Jones \& Holdgate (1980). The sample is from approximately one nautical mile $(1.85 \mathrm{~km})$ south of the western end of shallow seismic profile Line 28 illustrated on figure 4 of Jones \& Holdgate (1980). Although the correlation is imperfect, it suggests that the sample is part of the sequence of older rocks which appears to outcrop at this locality and to form the continental slope. In oil exploration well Clam-1, these were taken to be "hard brown limestone of Miocene age" (Port Campbell Limestone equivalent) (Jones \& Holdgate 1980).

Biostratigraphic interpretation of this sample is ambiguous, and several samples were processed. Sediments of at least two ages are present, but whether they were mixed by dredging or geological factors cannot be ascertained. The two ages are based on ranges of well-known planktonic species and of a benthic species which has not been recorded from Tasmania before.

The mixed planktonic fauna is characterised by a low diversity of planktonic species which are dominated by Globigerina bulloides d'Orbigny, small globigerines and Globorotalia scitula (Brady). Keeled globorotalids are rare. A single specimen of Orbulina universa d'Orbigny was recovered but is taken as possible contamination and,-thus, not significant stratigraphically. The fauna lacks sphaeroidinellids, pulleniatinids, hastigerinids or even the more complex variants of Globigerinoides trilobus (Reuss). The benthic fauna comprises $40 \%$ of the assemblage and is diverse but composed mostly of species that are not age diagnostic.

The younger fauna contains rare Globorotalia inflata (d'Orbigny), G. truncatulinoides (d'Orbigny) and G. tosaensis Takayanagi \& Saito (differentiated from G. truncatulinoides by being more heavily thickened, possessing a less open umbilicus and less well-developed keel). This fauna is consistent with deposition during the earliest Pleistocene N22 (Globorotalia [G.] truncatulinoides truncatulinoides Partialrange Zone of Blow 1969).

Several specimens of Globorotalia miozed Finlay also are present and indicate that at least part of the fauna is Early to Middle Miocene, N7-N15 (Globigerinatella insuetaGlobigerinoides quadrilobatus trilobus Partial-range Zone to Globorotalia continuosa Consecutive-range Zone of Blow 1969). 

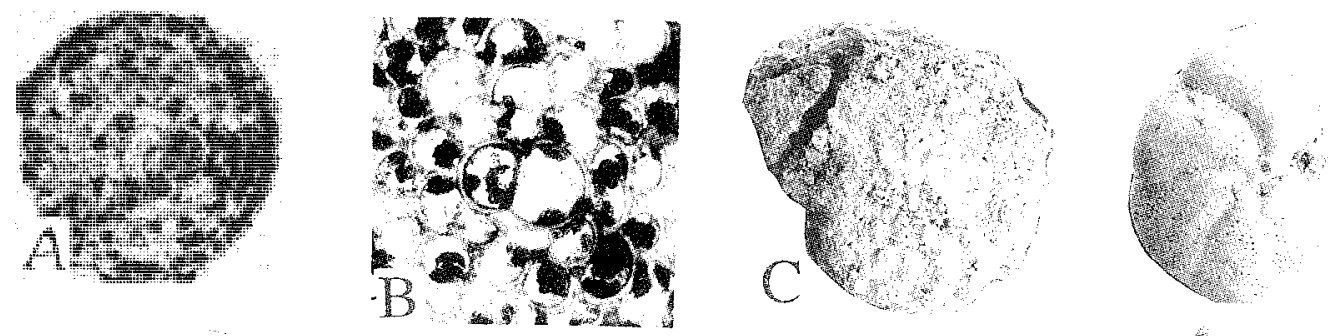

D
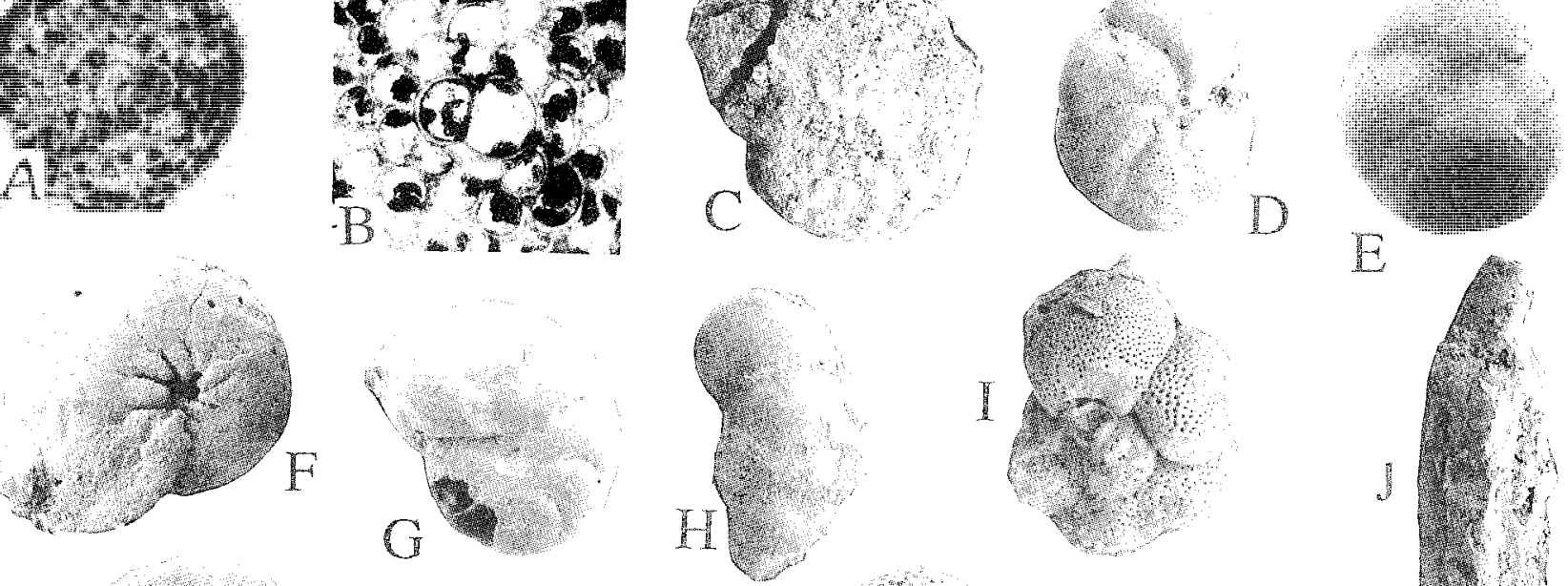

E
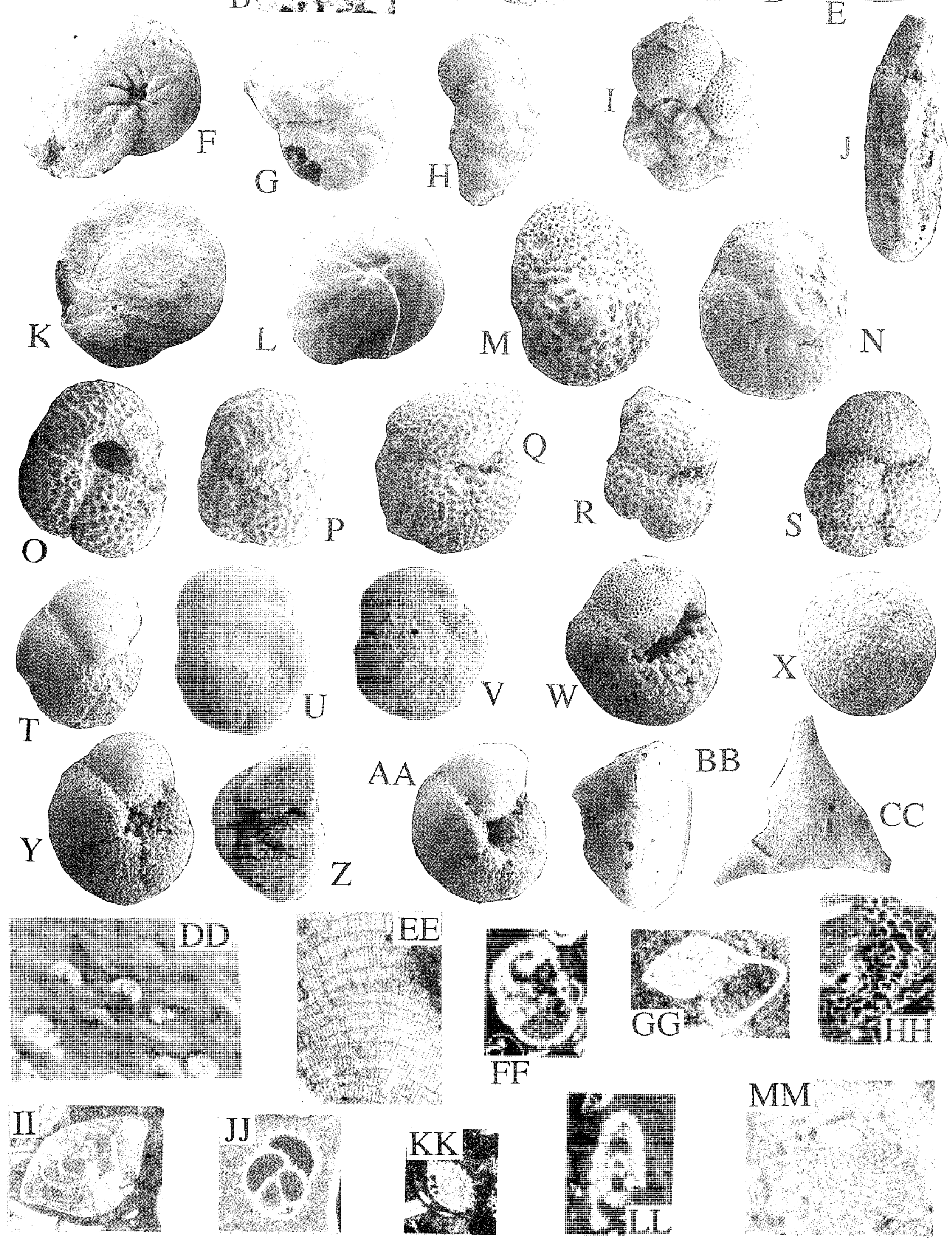
Several well-preserved specimens of Cibicidoides notocenicus (Dorreen) were recovered and originally identified as $C$. mexicanus (Nuttall). It seems that the two forms may be identical. C. mexicanus has a range from latest Eocene to Early Mio cene (P16-N5 of Blow 1969) (Van Morkhoven et al. 1986), and thus it represents a time period not represented by the planktonic faunas. It occurred in middle and lower bathyal depths $(600-2000 \mathrm{~m})$ and, thus, should cooccur with abundant contemporaneous planktonic forms.

The age of the oider fauna is not well constrained but probably belongs to the earlier part of the N7-N 15 interval given above, and is here taken as later part of the Early Miocene (N7-N8, if the New Zealand range of $C$. notocenicus is to be followed).

\section{Palaeoenvironment}

UTGD66532 contains material from several ages and several different marine environments of deposition which are difficult to isolate. The sample locality now lies in $560 \mathrm{~m}$ water depth, but all faunas are consistent with accumulation in a mid- to outer-continental shelf depth. The $58 \%$ planktonic content suggests some subsidence since deposition. Comparison with the distribution of individual species and species groups discussed by Bé \& Hutson (1977) indicates that the fauna is most similar to the living subpolar assemblage or the polar/subpolar fossil assemblage and that the waters at this location were colder in the past than they are now. The low diversity, virtual absence of keeled globorotalids and lack of many other groups common elsewhere also suggest that the water temperature was low during all intervals of deposition.

\section{UTGD66533 — offshore eastern Tasmania}

\section{Lithology}

Pale, well-sorted, massive bryozoal calcarenite described as "rocks from a coral patch", yielding large residue coarser than 125 microns. Some iron staining present and some foraminiferid chamber lumina filled with secondary iron oxide (Fe/Mn?). This occurrence may be similar in character to that of phosphates with goethite recorded by Jones 8 Davies (1983) in samples 2121 and 2126 from northwestern Tasmania. All carbonate grains are significantly overgrown, varying from light frosting to severe overgrowth on echinoderm fragments.

Additional fauna is very diverse in benthos and dominated by bryozoans, but also alcyonarians, bivalve fragments, rare, small, ribbed brachiopods, isocrinoid ossicles and echinoid spines.

\section{PLATE 1}

(A) Sherbornina cuneimarginata Wade, Penguin, UTGD124959, equatorial section, $\times 65^{*}$.

(B) Planorbulinella inaequilateralis (Heron-Allen \& Earland), Penguin, UTGD124960, equatorial section through embryonic chambers, $\times 125$.

(C) Operculina sp. A of Carter (1964), from UTGD66534 off northeastern Tasmania, UTGD124961, $\times 36$.

$(D, E)$ "Valvulineria" kalimnensis (Parr), Penguin, UTGD124962, ventral and dorsal views, $\times 55$.

(F) Astrononion centroplax Carter, southeastern Tasmania, UTGD124964, $\times 50$.

(G) Astrononion australe Cushman \& Edwards, Penguin, UTGD124965, $\times 90$.

(H) Karreria maoria (Finlay), from UTGD66534 off northeastern Tasmania, UTGD124966, dorsal view, $\times 55$.

(I) Carpenteria rotaliformis Chapman \& Crespin, southeastern Tasmania, UTGD124963, dorsal view, $\times 24$.

(J) Crenulostomina banksi Quilty, from southeastern Tasmania, UTGD124967, lateral view, $\times 30$.

$(K, L)$ Cibicidoides notocenicus Dorreen, offshore northwestern Tasmania, dorsal and ventral views, UTGD124968, (K) dorsal $\times 35$, (L) ventral $\times 38$.

$(M, N)$ Globorosalina scabricula (Chapman), Penguin, dorsal and ventral views, UTGD124969, $\times 38$.

(O) Globigerina woodi Jenkins, from off northeastern Tasmania, UTGD124970, ventral view, $\times 90$.

(P) Globigerina connecta Jenkins, Penguin, UTGD124971, ventral view, $\times 130$.

(Q) Globoquadrina dehiscens (Chapman, Parr \& Collins), off northeastern Tasmania, UTGD124972, ventral view, $\times 105$.

$(R, S)$ Globorotalia nana Bolli, off southeastern Tasmania, UTGD124973, ventral and dorsal views, $\times 90$.

$(T, U)$ Globorotalia scitula (Brady), offshore northwestern Tasmania, UTGD124974, ventral and dorsal views, $x 60$.

$(V, W)$ Globorotalia miozea Finlay, offshore northwestern Tasmania, UTGD124975, dorsal and ventral views, $\times 70$ and $\times 65$ respectively.

(X) Praeorbulina glomerosa circularis (Blow), offshore northeastern Tasmania, UTGD124976, $\times 105$.

$(Y, Z)$ Globorotalia tosaensis Takayanagi \& Saito, offshore northwestern Tasmania, UTGD124977, ventral and oblique apertural views $\times 70$ and $\times 65$ respectively.

$(A A, B B)$ Globorotalia truncatulinoides (d'Orbigny), off southeastern Tasmania, UTGD124978, ventral and oblique dorsal views, $\times 55$ and $\times 80$ respectively.

(CC) Triangulina aequilateralis Quilty, off southeastern Tasmania, UTGD124979, $\times 80$.

(DD-MM) Early Middle Miocene, Ocean Beach Strahan, UTGD124886. (DD) Mesophyllym/Lithophyllum sp., $\times 25$; (EE) Lithophyllum sp., $\times 50$; (FF) Carpenteria $c f$. rotaliformis Chapman and Crespin, $\times 25 ;(G G)$ Globorotalia scitula (Brady), $\times 95$; (HH) Acervulina inhaerens Schultze, $\times 27$; (II) Cibicides sp., $\times 60 ;$ (JJ) spinose buliminid, $\times 100$; (KK) Small Elphidium sp. indet., $\times 25$; (LL) Large Elphidium sp. indet., $\times 25$; (MM) Gypsina globulus (Reuss), $\times 55$.

* Most magnifications rounded to the nearest $5 x$. 


\section{Age}

The poorly preserved foraminiferid fauna is difficult to identify with certainty and, thus, the rock cannot be dated precisely. The benthic component (20-25\% of the fauna) contains Elphidium crespinde Cushman, Cibicides perforatus (Karrer), Gaudryina convexa (Karrer) and Pseudoclavulina cf. anglica Cushman, all of which are known from Early Miocene sediments in southeastern Australia, and some range into the Middle Miocene in Tasmania and even younger in New Zealand. The early Miocene age assignment is consistent with the presence of common Globigerina species (including $G$. connecta Jenkins), which dominate over the benthic component. Other planktonic genera are absent. There is no evidence of reworking. A few Quaternary species, including Globorotalia truncatulinoides, are present and probably result from some mixing during dredging.

Although the age is not well constrained, the sediment is estimated to be Early Miocene and probably equivalent to the Fossil Bluff section. This is the interval within the Early Miocene that seems to have had water remperature conditions that yielded planktonic foraminiferid faunas with composition and diversity similar to those listed here (Quilty 1972).

\section{Palaeoenvironment}

The fauna in UTGD66533 is so poorly preserved that even the planktonic/benthic ratio cannot be estimated accurately. Based on the low diversity and domination of the planktonic content by hispid Globigerina spp., it was deposited in cool water conditions.

The sediment is lithologically similar to some described from the Marrawah region (Quilcy 1972), which also have similar faunal composition, benthic and planktonic foraminiferid fauna and preservation, even if not age. They probably accumulated in similar palaeoenvironment on the inner to middle continental shelf, at depths of about $100 \mathrm{~m}$ or less, and at sites lacking significant sediment input. The sediment is well sorted, suggesting some current action, but there is no obvious abrasion of the foraminiferid tests, although preservation is inadequate to state this definitively. The sediment was recovered from over $1100 \mathrm{~m}$ and clearly has moved to its present depth, suggesting some continental margin slumping or downfaulting since the end of the Early Miocene.

\section{UTGD66534 — offshore eastern Tasmania}

\section{Lithology}

Massive white chalk which yielded a relatively large, wellpreserved residue coarser than 125 microns. Bryozoa dominant, with echinoids and foraminiferids constituting a small component. No obvious terrigenous detrital element.

\section{Age}

Approximately $20 \%$ of the foraminiferid fauna is composed of planktonic species, including Praeorbulina glomerosa circularis (Blow), Globoquadrina debiscens dehiscens
(Chapman, Parr \& Collins), Globorotalia miozea Finlay, Globigerina decoraperta Takayanagi \& Saito, and G. woodi woodi Jenkins. A single specimen of a form very similar to Globorotalia puncticulata (Deshayes) was found and appears to be out of place. No Globigerinoides spp. were recovered. Benthic forms include Operculina victoriensis, $O$. sp. (of Carter 1964), Cibicides mediocris Finlay, C. perforatus (Karrer) (dominant benthic), Karreria maoria (Finlay), Alabamina tenuimarginata (Chapman, Parr \& Collins) etc. It is a diverse fauna with low dominance.

Both planktonic and benthic species indicate an age on the Early-Middle Miocene boundary, that is N8 (Globigerinoides sicanus-Globigerinatella insueta Partial-range Zone) or N9 (Orbulina suturalis-Globorotalia peripheroronda Partial-range Zone of Blow 1969).

\section{Palaeoenvironment}

UTGD66534 is a warm, clear water, inner continental shelf sediment deposited in a low energy environment off a coast of low sediment input. It seems to have been deposited during an episode of high sea level, represented by sediment around most of the Australian coastline. It was recovered from $870 \mathrm{~m}$ and, thus, appears to be considerably below where it was deposited, perhaps by as much as $800 \mathrm{~m}$, indicative of tectonic subsidence of approximately that amount.

\section{UTGD66535, 66536 - offshore eastern Tasmania}

\section{Lithology}

UTGD66535 white chalk; 66536 indurated grey, nonbedded marl. Residue coarser than 125 microns from 66535 small and dominated by foraminiferids and sponge spicules, with minor bone fragments, ostracods and alcyonarian spicules. That from 66536 larger and dominated by bryozoa and two types of calcareous worm tubes. Echinoid spines and small gastropods subordinate.

\section{Age}

The samples are Quatcrnary in age, based on the presence in each of Globorotalia truncatulinoides truncatulinoides (d'Orbigny), the index species for the Quaternary. Differentiation of the two Quaternary zones in the Blow (1969) scheme is not possible with the material available. Both samples consist of high diversity, low dominance benthic faunas with $28 \%$ and $71 \%$ planktonics respectively. Pulleniatinids and sphacroidinellids are absent.

\section{Palaeoenvironment}

While UTGD66535 and 66536 are both Quaternary in age, in other ways they are very different. U'TGD66536 comes from farther offshore and from deeper water. Thus, it would be expected to contain a higher percentage of planktonic forms in the foraminiferid fauna and benthic 
forms indicative of deeper water deposition. In fact the converse is true. It contains less than $30 \%$ planktonic species, and almost half the benthic fraction is composed of miliolid forms, normally associated with reasonably shallow, inner shelf conditions of deposition. Textularia cf. hayi Karrer is the dominant benthic.

In contrast, UTGD66536, which is at present closer inshore and in shallower water, contains over $70 \%$ planktonic forms and a diverse plankronic species list. The benthic forms are diverse, and dominance (Walton 1964, Quilty 1972) is low, consistent with an outer continental shelfupper continental slope site of accumulation.

The differences between foraminiferid faunas in UTGD66535 and 66536 may have been caused by deposition during glacial intervals (when sea level was approximately $130 \mathrm{~m}$ lower than now, ocean waters cooler and planktonic faunas less diverse; UTGD66536) and interglacial (when sea level was high, the ocean warmer and planktonic faunas more diverse; UTGD66535). Such conditions alternated during the Quaternary on a regular $100-120 \mathrm{ka}$ cycle, perhaps in response to Milankovich forcing (Imbrie 1984, Goodess et al. 1992).

\section{ST HELENS HILLS}

The sample was studied from one large thin section of UTGD124871.

\section{Lithology}

Buff-coloured, highly indurated, matrix supported, micritic limestone with abundant and diverse macro- and microfossil content. Fabric of the sample highly disturbed, suggesting severe bioturbation or slumping to present locality. Most macrofossils broken. Echinoderm debris common; highly overgrown. Internal detail largely destroyed.

Age

The foraminiferid fauna is dominated by small, thin-walled globigerinids which are quite well preserved. These include Orbulina universa, Globoquadrina sp., Globigerinoides quadrilobatus (d'Orbigny), Globoquadrina altispira s.l., Sphaeroidinellopsis sp. (this appears not to be S. dehiscens, as no second aperture could be seen on the many sections encountered and the most similar form is S. subdehiscens subdehiscens Blow), Globorotalia (probably $G$. tumida [Brady]), Globorotalia (of the $G$. scitula type), Globigerina (of the thick-walled, three-chambered type such as G.woodi), $G$. venezuelana and possibly Pulleniatina (of the P. primalis rype). Kecled and nonkeeled globorotalids are rare. Also present is an unidentified highly spinose Globigerina.

The composition of the fauna suggests a Late Miocene age (N18, Globorotalia tumida tumida-Sphaeroidinellopsis subdehiscens paenedehiscens partial-range zone of Blow 1969).

\section{Palaeoenvironment}

Deposition occurred in fully marine conditions adjacent to a source of coarse macrofauna, in water dcep cnough for the dominant sediment input to be pelagic. There is very little terrigenous material other than in the micritic fraction. This indicates either that runoff was low, or that the site of deposition was isolated from the mainland by a deeper water region. Water temperature was temperate, similar to the present-day environment.

\section{AURORA AUSTRALIS SAMPLE}

Site of deposition

Echo sounder information suggests that the site is on a flattopped submarine plateau at about $800 \mathrm{~m}$. Between the plateau and the continental shelf edge there is a deeper channel.

\section{Lithology}

A mixture of bryozoal calcarenite fragments, up to 30$40 \mathrm{~mm}$ in size, broken from parent rock during coring, and minor soft "modern" sediment. The more lithified sediment is compact, white, moderately lithified, well-sorted, bryozoal calcarenite, apparently unbedded. It contains abundant echinoderm debris, alcyonarian remains and bryozoa. Small, ribbed brachiopods rare. Most fossils well preserved but echinoderm debris commonly substantially overgrown. Terrigenous detritus a very minor component of the 125250 micron fraction. Calcarenite surface marked by brown iron staining in zone about $5 \mathrm{~mm}$ thick, suggesting it marks a hardground on which younger sediment is accumulating. Because of the mixed nature of the sediment, samples reported here were carefully chosen and washed before crushing and processing, to ensure that there has been no mixing of the younger with the older.

The well-lithified sediment is overlain by soft sediment, which is carbonate rich with abundant foraminiferids.

\section{Age}

In the well-lithified sediment, foraminiferids constitute a small volume of the residue but are well preserved. Planktonic species are a very minor component (much less than $1 \%$ ) of the fauna and only Globigerina woodi, $G$. bulloides and Globorotalia nana Bolli were recovered. Benthic forms are diverse and dominated by Cibicides perforatus. Few of the key species in the southeastern Australian biostratigraphic schemes of Carter $(1958,1964)$ are present, but Astrononion centroplax Carter, Carpenteria rotaliformis Chapman and Crespin, Notorotalia howchini (Chapman, Parr \& Collins) and Elphidium crespinae Cushman, together with the planktonic species listed above, suggest that the fauna is from the earlier part of the Early Miocene (or perhaps very latest Oligocene). The problematic form Triangulina aequilateralis Quilty (Quilty 1970) was described from the earliest Miocene of Cape Grim and also is found here but is very rare. 

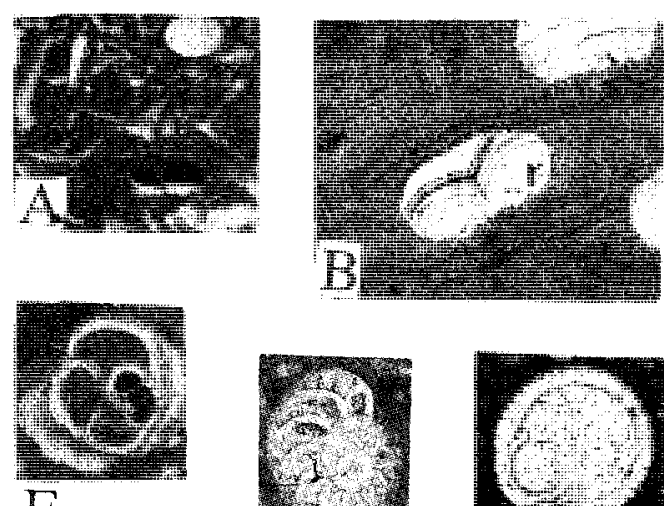

F
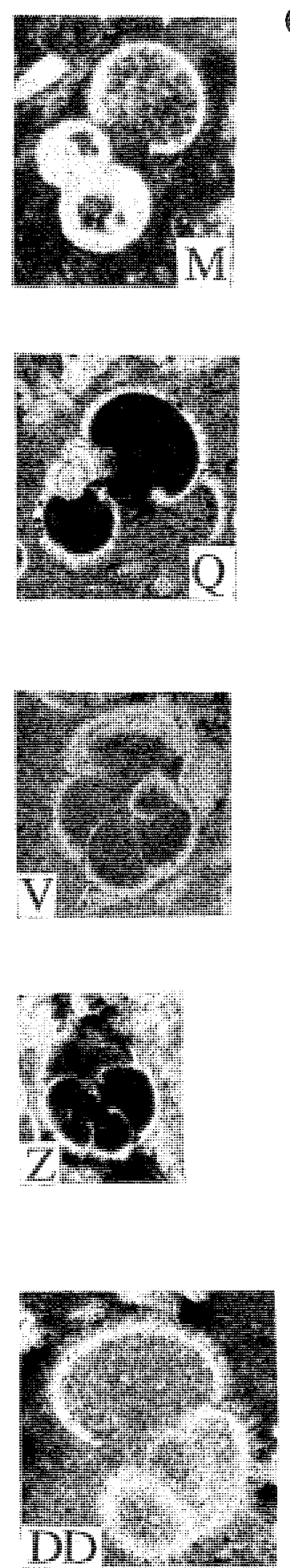

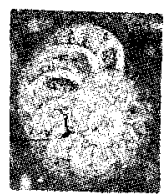

G

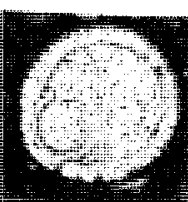

$\mathrm{H}$
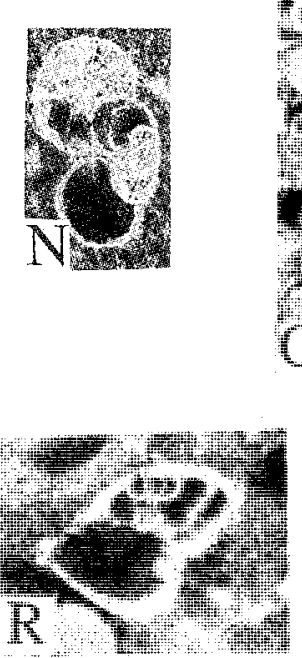
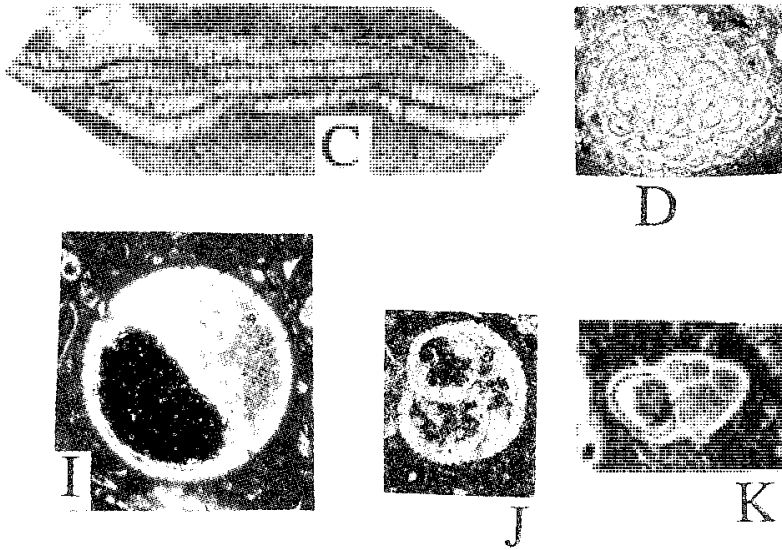

D
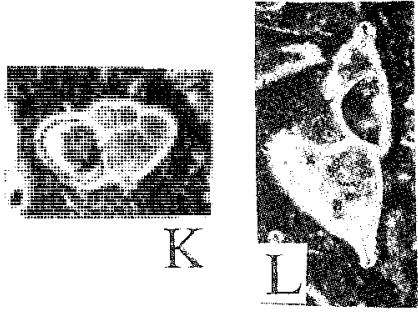

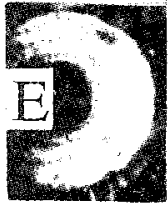

K
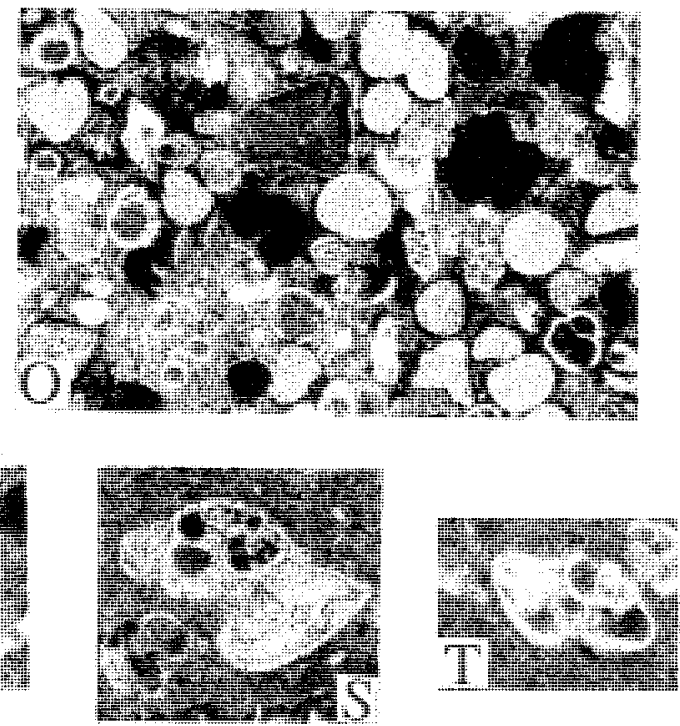
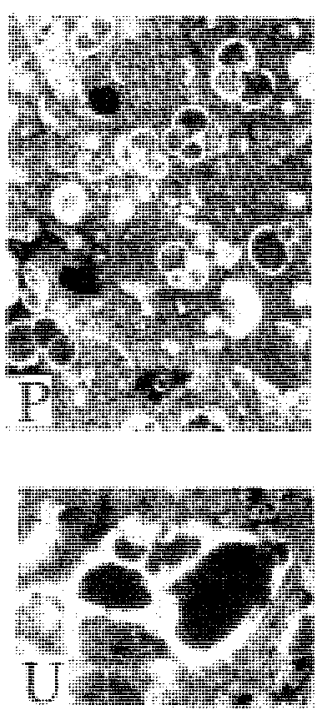
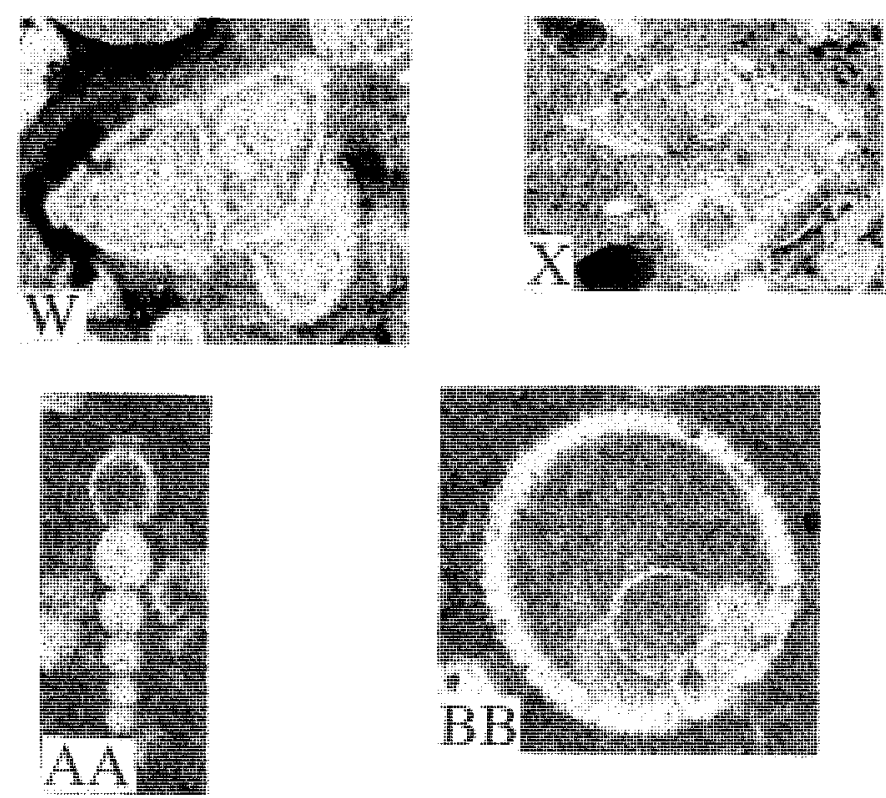

$\mathrm{EE}$ Hest= (at) +4)
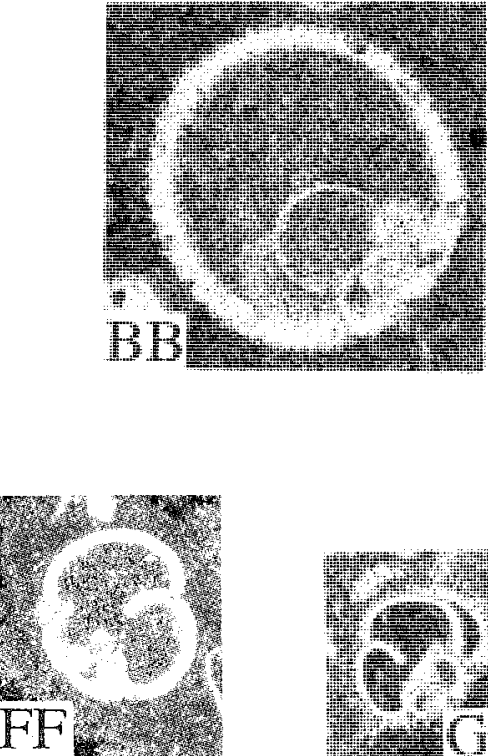

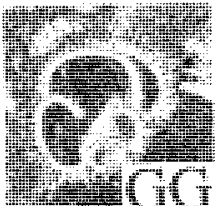

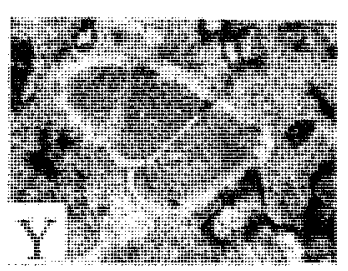
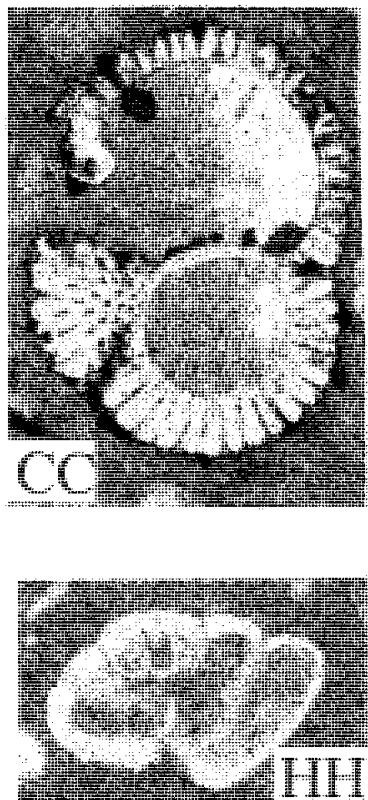
The overlying younger sediment was not well sampled by the core, but planktonic species constitute over $90 \%$ of the foraminiferid fauna and include abundant Globorotalia inflata and rare $G$. truncatulinoides, indicating a Quaternary age. Otoliths include those from myctophids (lanternfish) and others.

This sample provides the first palaeogeographic evidence from the pre-Quaternary Cenozoic of southeastern Tasmania and is the first step in redressing the problem of lack of samples of much of the Tertiary, noted by Colhoun in Burrett \& Martin (1989: 409).

\section{Palaeoenvironment}

The Early Miocene sediment was deposited in shallow water. It has a very low planktonic content and probably accumulated off a coast with low runoff. Water depth was probably less than $20 \mathrm{~m}$, and that depth probably precludes the full diversity of planktonic forms being incorporated. There is not enough information to comment on water temperature at the time, other than that there are no indices of subtropical/tropical or even warm temperate conditions. This perhaps supports an earlier, rather than a later Early Miocene age determination.

The Quaternary sediment is characterised by sinistrally coiled Globorotalia truncatulinoides, which indicates deposition in cool water.

\section{OCEAN BEACH SAMPLES}

One thin section was studied from each of the six rock samples collected. This material was not recorded in the review of Macquarie Harbour Graben sediments contained in Baillie \& Corbett (1985). Lithology is variable from bryozoal calcarenite to conglomerate with interstitial bryozoal debris. Three separate rock types appear to be present and a fourth is a mixture of two as a conglomerate.

\section{UTGD124886}

The most complex of six samples recovered. Conglomerate with well-rounded, high sphericity pebbles of calcarenite to about $30 \mathrm{~mm}$, embedded in grey matrix which seems to represent significantly younger, shallower water phase.

Older material consists of yellowish to reddish-brown, uniformly medium-grained calcarenite. Foraminiferids the dominant fossil group, but some bryozoa, echinoid spines and rare calcareous algae also present. Benthic foraminiferids subordinate to planktonics.

The older material is early $\mathrm{N9}$ in age, based on the presence inter alia of Praeorbulina, Orbulina universa, Globoquadrina, Globorotalia scitula and Globigerina of the woodi group. Small, thin-walled, four-chambered globigerinids also are common.

The grey matrix is much coarser, poorly sorted and highly porous. Where the porosity is low, it is due to the filling of the interstices by uniform, very fine, grey micrite. This phase consists of highly fragmented bryozoan calcarenite with common calcareous algae, serpulids and broken mollusc fragments. Foraminiferids are less common than in the reddish phase and benthics are dominant over planktonics.

This phase is much younger than the framework of the pebbles and the planktonic foraminiferid fauna less common. Benthic forms include Elphidium spp. (both large and small species), Carpenteria cf. rotaliformis, Acervulina inhaerens, Notorotalia and miliolids. This phase seems to be Late Miocene, $\mathrm{N} 18$ in age.

\section{UTGD 124887}

Grey, roughly laminated limestone dominated by calcareous algae, bryozoans and gastropods, with other minor molluscs and echinoids. Interstices filled with very fine (but not micritic) sediment, including some fine, angular, terrigenous material and sponge spicules. Foraminiferids identified, while uncommon, come from this lithology and include

Early Middle Miocene, Ocean Beach Strahan, western Tasmania.

(A-G) From UTGD124487. (A) Sponge spicules in rock thin section, $\times 25^{*}$; (B) Mesophyllum/Lithophyilum sp., $\times 70$; (C) Lithoporella sp., $\times 65$; (D) Gypsina globulus, $\times 55$; (E) Sherbornina sp., $\times 65$; (F) Globoquadrina dehiscens (Chapman, Parr and Collins), $\times 65$; $(G)$ Elphidium sp., $\times 65$.

(H-I) From UTGD124888. (H) Praeorbulina glomerosa Blow, section through embryonic chambers, $\times 70$; (I) Orbulina universa d'Orbigny, $\times 45$.

(J-N) From UTGD124889. (J) Globigerinita sp., $\times 70 ;(K)$ Globorotalia scitula (Brady), $\times 80 ;(L)$ Globorotalia $c f$. conoidea Walters, $\times 65 ;(M)$ Globigerinoides quadrilobatus (d'Orbigny), $\times 105$; (N) Globigerina angustiumbilicata Bolli, $\times 200$.

$(O-Z)$ From UTGD124891. (O) Lithology showing phase with abundant glauconite grains, $\times 45$; (P) Lithology showing abundance of planktonic foraminiferids, $\times 50 ;(Q)$ Globigerina angustiumbilicata, $\times 100 ;(R, S)$ Globorotalia conoidea/miozea, vertical sections, $\times 120$ and $\times 150$ respectively; (T) Globorotalia scitula (Brady), vertical section, $\times 105$; (U) Globorotalia conoidea Walters, $\times 110 ;(V-Y)$ Globorotalia (?) conomiozea Kennett, (V) equatorial section, $\times 110,(W-Y)$ vertical sections, $\times 110,160$ and 110 respectively; (Z) Globoquadrina sp., $\times 190$.

(AA-HH) All Late Miocene, St Helens Hills, UTGD124871. (AA) Stilostomella sp., longitudinal section, $\times 30 ;(B B)$ Orbulina universa, $\times 1$ 10; (CC) Sphaeroidinellopsis sp., X105; (DD, EE) Globoquadrina cf. dehiscens (Chapman, Parr \& Collins), vertical sections, $\times 115$ and $\times 45$ respectively; (FF) Globigerina venezuelana (Hedberg), vertical section, $\times 45$; (GG) highly spinose globigerinid, vertical section, $\times 40 ;(H H)$ Globorotalia scitula, $\times 110$.

* Most magnifications rounded to the nearest $5 \times$. 
Sherbornina, Globoquadrina dehiscens, small Elphidium and Gypsina globulus. These are not age diagnostic but are consistent with the Middle Miocene age identified in some of the other Ocean Beach samples. This rock has been burrowed to a minor extent and the burrows are infilled with angular detrital material from which no fossils have been recovered.

\section{UTGD124888-124890}

Each of three samples consists of single lithology which is reddish or yellowish brown, highly calcareous with common bryozoans, minor calcareous algae, weak bedding accentuated by alignment of the bryozoans, and matrix supported with abundant, thin-walled globigerinids. Fine, curved fragments are common and may be ostracod or pteropod remnants. Fragmentation of components common, but rounding not evident.

UTGD124888 contains Orbulina universa, Praeorbulina glomerosa, Globorotalia cf. miozed, G. scitula, Globoquadrina etc.

UTGD124889 and 124890 very similar to 124888 but bedding less obvious and sponge spicules abundant in the matrix. Pteropods are identifiable in this slide only. Foraminiferids, while abundant, do not include age diagnostic forms. Globorotalia cf. conoidea is present. 124890 contains what appears to be Globorotalia conomiozea, which would indicate an age younger than the early Middle Miocene documented above for other samples from Ocean Beach.

\section{UTGD124891}

Sand-sized pellets or tubular structures, $2-5 \mathrm{~mm}$ in diameter, which have a marked concentric structure. Terrigenous material not abundant, but silt-sized grains are angular and coarser grains well rounded. Other fossil debris includes abundant but poorly defined small sponge spicules, echinoid spines and broken and rounded bivalve fragments. Sample also has patches dominated by rounded glauconite grains, interstitial between the concentric structures. Globorotalia (?) conomiozed also is present, even quite common, in this sample.

\section{Age}

Foraminiferid and other faunas vary greatly from sample to sample but are generally dominated by small, thin-walled globigerinids. Keeled globorotalids are rare. Benthic fotms include Elphidium, Karreria, gavelinellids, and occasionally abundant miliolids. Pulleniatinids and other Late Miocene and Quaternary planktonic forms are absent. The foraminiferid fauna is listed on table 2. Calcareous algae ate a feature of most specimens and include Mesophyllum/ Lithophyllum and Lithoporella.

UTGD124887 contains Orbulina universa (several sections) and Praeorbulina glomerosa, showing that this specimen, at least, is very early Middle Miocene (early N9, Orbulina suturalis-Globorotalia peripheroronda Partial-range Zone of Blow 1969). Praeorbulina has also been seen in a thin section of UTGD124886. Other specimens contain abundant thin-shelled forms including a common five- chambered globigerinid that is probably $G$. angustiumbilicata, and $G$. woodi, Globorotalia scitula, G. cf. conoidea Walters, G. miozea, Sphaeroidinellopsis sp., Globoquadrina altispira, Globigerinita sp. and the benthic forms, Sherbornina sp., Elphidium spp., Karreria maoria, Gypsina globulus (Reuss), Cibicides of. perforatus, Textularia sp., miliolids and buliminids. The absence of pulleniatinids from all samples suggests an age older than Late Miocene for the entire specimen collection.

A form that appears to be Globorotalia conomiozed is present in UTGD124890 and 124891. It is possible that two ages are represented in both the sample collection and in individual samples. In addition to the early Middle Miocene age documented here, it is possible that lithified Middle Miocene fragments have been reworked into the grey limestone which is Late Miocene, probably N18 (Globorotalia tumida tumida-Sphaeroidinellopsis subdehiscens paenedehiscens Partial-range Zone of Blow 1969). However, any suggestion of Late Miocene is very tentative.

\section{Palaeoenvironment}

The variation in lithology and fossil content suggests an origin in a "shallow" water, fully marine environment, at a time of high energy. Abundant calcareous algae in some specimens indicate a depth limit in the photic zone, perhaps $70 \mathrm{~m}$ or shallower. Rounding and breakage of fossils and the abundance of coarse terrigenous material are also consistent with this hypothesis but probably support a depth of deposition considerably less than $70 \mathrm{~m}$. Other specimens lack the algae and have high proportions of planktonic species, which suggests a deeper water, perhaps outer continental shelf depth of deposition. A significant part of the breakage seems due to postdepositional compaction effects.

The red/brown material has a higher planktonic foraminiferid content, suggesting deeper water deposition (still within the photic zone to judge from the calcareous algae) and perhaps a period of exposure to allow development of a ferruginous character and also erosion to generate rounding and redeposition. The grey, bryozoan/molluscl algae rich content is a younger, shallower water, higher energy component.

\section{COMPARISON WITH MODERN TASMANIAN SHELF SEDIMENTS}

Jones \& Davies (1983) summarised what is known of the distribution of modern sediments on the Tasmanian continental shelf and through most of Bass Strait. For that study, 365 localities were sampled and analysed for grain size, composition, heavy mineral content etc. This collection of samples has provided the basis for other studies such as that by Rao \& Adabi (1992, and references therein). The modern material studied by Jones and Davies and by Rao and Adabi has in common with older Neogene sediments around Tasmania that it seems generally to be cold water carbonate dominated, with the exception of one interval at the close of the Early Miocene and earliest Middle Miocene, when conditions were much warmer. Unfortunately, little attention was given by Jones \& Davies (1983) to biogenic content other than for molluses and pollen (three samples 
only), although reference was made to unpublished foraminiferid data of Taylor and Mee, which indicate that the benthic component is quite different from that recorded from the older samples. In contrast to the modern samples recorded by Jones \& Davies (1983), the material recorded herein generally contains little molluscan debris. Jones \& Davies' samples were generally from less than $100 \mathrm{~m}$ water depth, a few to about $200 \mathrm{~m}$, and only one unsuccessful attempt (locality 2029) was made to obtain material from significantly deeper waters - $823 \mathrm{~m}$. This latter sampling was within a few kilometres of UTGD66535 (see below). Similarly, sample location 2119 in $170 \mathrm{~m}$ was within a few kilometres of UTGD66532.

Jones \& Holdgate (1980) referred to Miocene sediment from shallow depth in the ofl exploration well Clam-1, off northwestern Tasmania, and it is probable that what has been recorded here from UTGD66532 is part of that sequence which outcrops on the seafloor.
Exon et al. (1992) recorded sediments from core, grab and dredge samples along the west coast of Tasmania. Dredge samples in areas close to those examined for this paper are Cretaceous. Cores 45 and 46 contained Late Pliocene sediments deposited under cold surface water conditions. Core 40 consisted of shallow water Early Miocene overlain by Quaternary. The grab samples contained only modern material and will be discussed no further.

\section{TASMANIAN NEOGENE MARINE SEDIMENTATION PATTERNS}

By the beginning of the Miocene, Australia and Antarctica had separated (Veevers et al. 1991) sufficiently to allow open circulation, both shallow and deep, between the continents from the Indian to Pacific Oceans, as part of a circurnpolar system that exists today (see Kemp 1978,

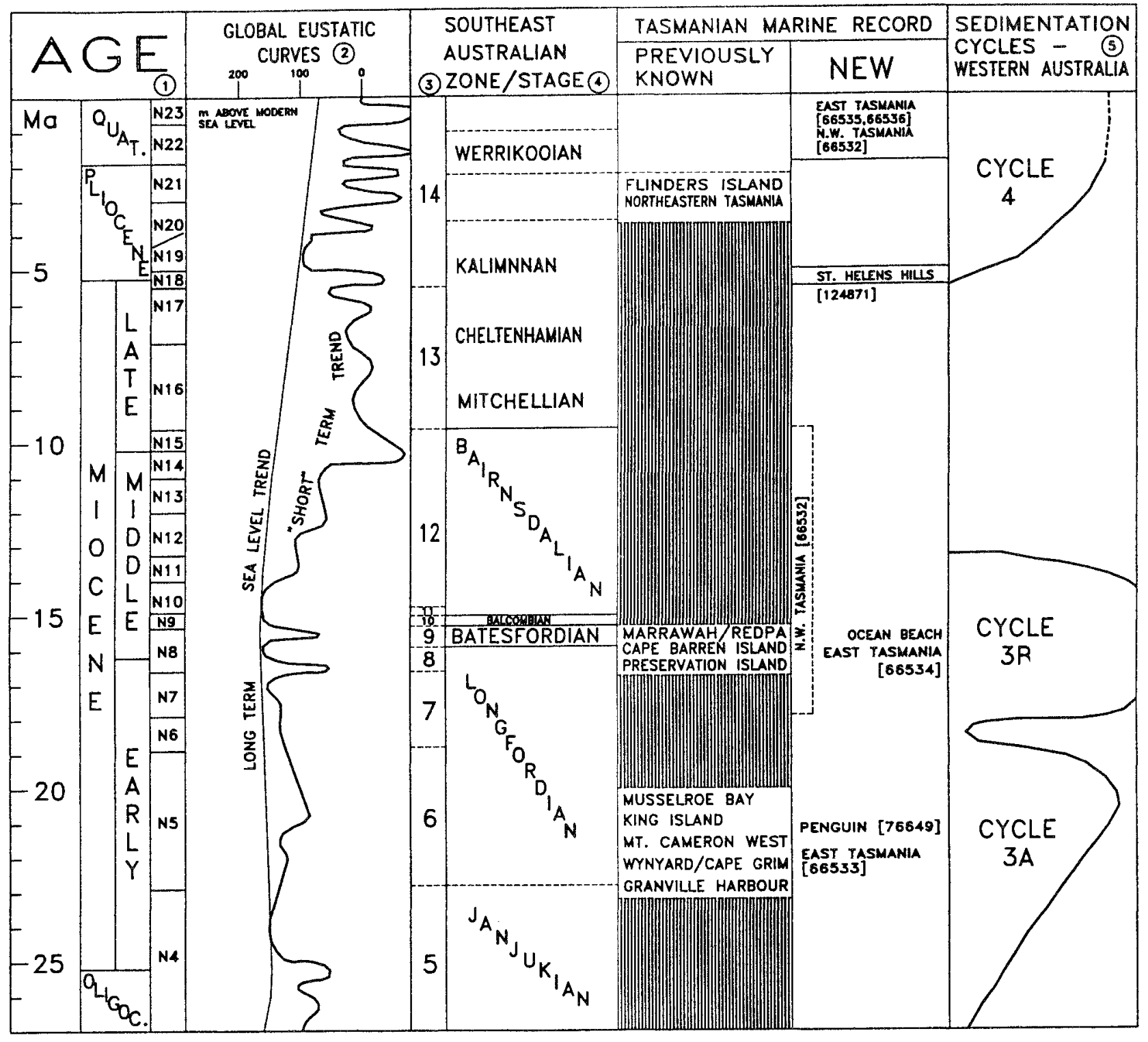

FIG. 3 - Integration of new data into general correlation scheme for all Tasmanian marine sediment sections. (1) Planktonic foraminiferid zonal scheme of Blow (1969). (2) Correlation of age and global eustatic curves taken from Haq et al. (1987). (3) Carter (1958) Faunal Unit scheme. (4) Correlation of Faunal Units and Australian stages from Abele in Douglas \& Ferguson (1976). (5) Western Australian sedimentation cycles from Quilty (1977). 
Vee vers 1984). For the first time, Australia became independent of the direct influence of Antarctica, in contrast withconditions earlier. There were marine conditions and shallow water flow from west to east through Bass Strait. Tect nically, the region was relatively inactive, other than for changes in latitude due to seafloor spreading. Volcanism was active onshore in Tasmania during the Miocene (Sutherland \& Wellman 1986) and also intruded into offshore marine sequences (Burrett \& Martin 1989). It seems, therefore, that the principal influences on Tasmanian sea-Ievel change and climate were global rather than purely local.

O nly a small proportion of Neogene time is represented by marine sediments recorded here in and around 'Tasmania and, thus, any reconstruction of Neogene history based on the marine record alone is incomplete and biassed towards short intervals of time. This is in contrast with the situation in much of southeastern Australia, where more continuous sections are known, and is probably due to the lack of basinal structures in the Cenozoic of Tasmania, other than graben, and control of marine sedimentation patterns by eustatic sea level variation.

Study of all known sections and records from many isolated sections reinforces the indications, outlined in Quilty (1972, 1985a, b), that the discontinuous Tasmanian marine record reflects a series of episodes of deposition in the earliest Miocene, very late in the Early Miocene and/or earliest Middle Miocene, Early and Late Pliocene and at different times through the Quaternary. Most of the preQuaternary episodes are represented by several sections and isolated samples. The Late Miocene is represented in only one sample seen to date and that was deposited in much deeper water conditions than sediments of other ages. The earlier part of the Middle Miocene is identified only from those samples deposited in N9 time, probably as a continuation of the episode of deposition in the latest Early Miocene. This study indicates that the latest Middle Miocene (N14/15 of Blow 1969) may be present. This is unusual in Australian Cenozoic sections.

The records appear to represent carbonate sedimentation during intervals of globally warmer water conditions and high sea level. These coincide generally with a similar sequence of episodes of deposition elsewhere around Australia, documented by Quilty (1977b, 1980b) and McGowran (1979) and McGowran \& Li (1993). Figure 3 includes a compilation of the international eustatic sea-level curve produced by Haq et al. (1987), based on those of Vail et al. (1977). On what earlier authors have termed the short-term sea-level curve, there is shown to be a series of generally higher sea levels including one in the very Early Miocene (N4/5), a series of peaks at the Early/Middle Miocene boundary (including N8 and N9) and one in the Early Pliocene (N19/20). The Early/Middle Miocene events seem to represent the interval of highest Neogene sea level that also coincides, from the Tasmanian and other southern (McGowran \& Li 1993), eastern (Quilty 1993) and western Australian evidence, with a time of very warm marine conditions, marked by carbonates and the presence, even in Tasmania, of large, subtropical or warmer foraminiferids such as Lepidocyclina. This probably was the interval of warmest conditions that surrounded Australia during the Cenozoic. Figure 3 also shows the Western Australian sedimentation cycles described by Quilty (1977b, 1980b). Cycles $3 \mathrm{~A}$ and $3 \mathrm{~B}$ have been identified in the Gippsland
Basin (McGowran \& Li 1993) and have been resolved into a more detailed transgression/regression record. This level of differentiation is at yet impossible in the Tasmanian sequence. The $\mathrm{N} 14 / 15$ record does not fit the pattern at all.

The earlier Miocene high sea-level event is not marked by warm water genera, such as Lepidocyclina, but does include the warm temperate (and warmer) genus Operculina at Penguin and at Doctors Rocks near Fossil Bluff. The fauna from southeastern Tasmania suggests cooler water than at Penguin/Doctors Rocks, perhaps due to different water masses operating. Kennett (1977) developed a scenario of circulation for the latest Oligocene, of cooler water from the south in southeastern Tasmania and warmer water from the west through Bass Strait. The results here indicate that this may have continued into the earliest Miocene. Kennett et al. (1985) suggested that the region was temperate in the Early Miocene, which is consistent with this interpretation. Sedimentation during this interval includes a significant noncarbonate component in the Fossil Bluff-Penguin area. Elsewhere, for example southeast of Tasman Island, and in Musselroe Bay (northeastern Tasmania), this was an interval of carbonate sedimentation.

The Pliocene sea-level high is relative only to sea levels immediately before and since and seems not to have been as high as during any of the Miocene events; nor is it represented by larger foraminiferid species of warm water aspect.

Thus, the Tasmanian marine sediment record, as far as it is known, is typical of what would be expected of a passive margin influenced by variations in sea level. The gaps in the sediment record dominate the stratigraphic column and appear to represent times of regionally low sea level. In most sedimentation cycles, the sediments seem to represent warm or relatively warm water sedimentation, and this seems to be regional in extent as noted above.

Loutit et al. (1983) and Kennett \& Von der Borch (1985) summarised the Deep Sea Drilling Project contribution to palacoccanography and water temperature for the southwest Pacific Ocean. Loutit et al. included data from Sites 279 and 281, which are southeast and south of Tasmania respectively, and quoted convincing evidence for an Early Miocene that was warmer than the Middle and Late Miocene, with a major cooling event during the interval 15-13 Ma, consistent with the evidence preserved around Tasmania. They also differentiated two warm phases within the Early Miocene, at 20.5 Ma and $16.5 \mathrm{Ma}$ although their data began at about $20.5 \mathrm{Ma}$, younger than the oldest material included in this paper. Kennett et al. (1985) referred to the lowest $\delta^{18} \mathrm{O}$ of the Neogene as being in the latter part of the Early Miocene and, thus, consistent with this being the warmest water of the Neogene, in turn consistent with the indications for Tasmania of the Lepidocyclina fauna.

Sediments marking the earliest Miocene transgression (N4/5; Faunal Unit 6) are known from north (both west and east parts) and from offshore southeastern and northeastern Tasmania. In contrast, the latest Early Miocene-Middle Miocene (N8/9; Faunal Unit 8/9) sediments are recorded onshore only from Marrawah in far northwestern Tasmania, through CSIRO sample 66534, to Ocean Beach. Late Miocene and younger sections are poorly known, and more samples are needed before generalisations can be made. So far, they are known from Flinders Island and offshore northeastern Tasmania only, perhaps largely because of sampling peculiarities. 


\section{IMPLICATIONS FOR NEOGENE TECTONISM}

Several of the samples examined in this study contain evidence of the depth of water at the time and site of deposition. The present water depth is often inconsistent with an hypothesis that suggests there has been no postdepositional vertical movement. For example, UTGD 66534 was deposited in about $50 \mathrm{~m}$ water depth but now lies in $870 \mathrm{~m}$ and the Aurora Australis sample was deposited in less than $20 \mathrm{~m}$ but now lies in $810 \mathrm{~m}$. Differences due to eustasy are much less than $800 \mathrm{~m}$, suggesting that sediments at the locality have moved into deeper wates either by slumping or continental margin downwarp or faulting. The differences are of the order of $400-1000 \mathrm{~m}$, but no consistent trend with age is obvious. It is clear, however, that significant movement has taken place. Many more locations need to be sampled before any trend can be found reliable.

\section{CONCLUSIONS}

Samples studied in this paper all were deposited in the Neogene. The more samples are collected, the more it becomes clear that this interval is the one which is most important around Tasmania for marine Cenozoic deposition, because no marine foraminiferid faunas older than this are known from Tasmania onshore or offshore, except in sections penetrated during hydrocarbon exploration. These are from Bass Strait and from offshore west coast Tasmania (fig. 1).

The sediment record is consistent with intermittent deposition during intervals of high sea level on the global eustatic sea-level curves, such as those compiled by Vail et al. (1977) and Haq et al. (1987). It is further consistenr with the history of deposition recorded from elsewhere around Australia. It further highlights the lack of information from the marine environment for most of the Middle and Late Miocene across southern Australia.

The warmest water conditions were at the close of the Early Miocene and earliest Middle Miocene, consistent with indications from earlier onshore studies (Quilty 1972).

None of the carliest Miocene faunas documented from the samples studied here represents a warm interval, although the presence of Operculina at Penguin and in UTGD66534 does indicate warmer conditions during deposition of those sediments than exist at present.

Neogene carbonate sedimentation occurred farther south on both eastern and western Tasmanian coasts than has been recorded previously.

Water temperature conditions during deposition varied from time to time, and the results available are consistent with southwest Pacific Ocean temperature history as documenred by Kennert et al. (1985).

There has been significant postdepositional vertical movement of several hundred metres of some of the sediment sections.

\section{ACKNOWLEDGEMENTS}

The senior author is very grateful to those (including the co-author) who have seen the value of what is otherwise apparently unwanted material. Ms P. Williamson, Curator, and Mr G. Davidson, at the Geology Department, University of Tasmania, recognised the potential value of the CSIRO samples. Dr W.A. Berggren helped with idencification of fauna in UTGD66532. Mr Clive Liron, CSIRO, helped significantly by finding information on Soela cruises S03/ 86 and S04/86, as did Mr R. Kloser for Southern Surveyor cruise S53/92. Mr John Marshall, Australian Geological Survey Organisation (AGSO) helped identify relevant literature. Mr S. Stephens and Ms K. Stait, University of Tasmania, identified the source of the offshore St Helens material. I also thank my shipboard companions during the testing that led to the Aurora Australis core. Mr R. Williams, Antarctic Division, identified the otoliths. Drafting was done by John Cox of the Antarctic Division.

Dr G. C. H. Chaproniere (AGSO), Dr A. McMinn, University of Tasmania, and Ms P. Waddington, Antarctic Division, reviewed a draft of the paper which led to many improvements.

\section{REFERENCES}

BaLsiLle, G.D., 1936: Large land slip near Ulverstone, Tasmania, arrested by deep drainage. Trans. Inst. Eng., Aust. 8: $365-371$

Bail...t, P.W. \& Corbett, K.D., 1985: Strahan, Tasmania. Tasm. Dept Mines 1:50,000 Geol. Atlas ser., Explan. Rep. Sheet $57(7913 \mathrm{~N}): 1-76$.

Bé, A.W.H. \& Hutson, W.H., 1977: Ecology of planktonic foraminifera and biogeographic patterns of life and fossil assemblages in the Indian Ocean. Micropaleont. 23: 369 414.

Brow, W.H., 1969: Late Middle Eocene to Recent planktonic foraminiferal biostratigraphy. In Bronnimann, P. \& Renz H.H. (Eds): PROC. FIRST INTERNAT. CONF. PLANKTONIC MICROFOSSILS, GENEVA. Brill, Leiden 1: 199-421.

Burrett, C.F. \& Martin, E.L., (Eds.) 1989: GEOLOGY AND MINERAL RESOURCES OF TASMANIA. Geol. Soc. Aust. Spec. Publ. 15: 574 pp.

CARTER, A.N., 1958: Tertiary foraminifera from the Aire District, Victoria. Bull. Geol. Soc. Vict. 55: 1-76.

Carter, A.N., 1964: Tertiary foraminifera from Gippsland, Victoria and their stratigraphical significance. Mem. Geol. Soc. Vict. 23: 1-154.

Douglas, J.G. \& Ferguson, J.A., 1976: GEOLOGY OF VICTORIA. Geol. Soc. Aust. Spec. Publ. 5, :528 pp.

Exon, N.F., Lef, C-S., Fflton, E.A., Hfggie, D., McKirdy, D., Penney, C., Shafik, S., Stephenson, A. \& Wilson, C., 1992: BMR cruise 67: Otway Basin and west Tasmanian sampling. Rep. Bur. Miner. Resour. Geol. Geophys. Aust. 306: $1-171$.

Gondess, C.M., Palutikof, J.P. \& Davies, T.D., 1992: THE NATURE AND CAUSES OF CLIMATE CHANGE. Belhaven Press, London: 1-248.

Haq, B.U., Hardenbol, J. \& Vail, P.R., 1987: The new chronostratigraphic basis of Cenozoic and Mesozoic sea level cycles. Cushman Found. Foramin. Res. Spec. Publ. 24: $7-13$.

ImBRIE, J. (Ed.), 1984: MILANKOVITCH AND CLIMATE. NATO ASI, 2 vols.

Jenkins, D.G., 1971: New Zealand Cenozoic planktonic foraminifera. Paleont. Bull. NZ Geol. Surv, 42: 1-278. 
Jevkins, D.G., 1985: Medicerranean Miocene and Pliocene planktic foraminifera. In Bolli, H. M., Saunders, J. B. \& Perch-Nielsen, K. (Eds): PLANKTON STRATIGRAPHY, Cambridge University Press: 263-282.

Jones, H.A. \& Davies, P.J., 1983: Superficial sedimenrs of the Tasmanian continental shelf and part of Bass Strait. Bull. Bur. Miner. Resour. Geol. Geophys. Aust. 218: 1-25.

Jones, H.A. \& Holdgate, G.R., 1980: Shallow structure and late Cainozoic geological history of western Bass Strait and the west Tasmanian shelf. BMR J. Aust. Geol. Geophys. 5: 87-93.

Kemp, E.M., 1978: Tertiary climatic evolution and vegetation history in the Southeast Indian Ocean region. Palaeogeogr., Palaeoclim., Palaeoecol. 24: 169-208.

Kennetr, J.P., 1977: Cenozoic evolution of Antarctic glaciation, the Circum-Anrarctic Ocean, and their impact on global paleoceanography. J. Geophys. Res. 82: 3843-3860.

Kannetr, J. P. \& Srinivasan, S., 1983: NEOGENE PLANK TONIC FORAMINIFERA. Hurchinson Ross, Stroudsburg: $1-263$.

Kennett, J.P. \& von der Borch, C.C., 1985: Southwest Pacific Cenozoic paleoceanography. Initial Reps Deep Sea Drilling Proj., 90: 1493-1516.

Kennett, J.P., Kellifr, G. \& Srinivasan, M.S., 1985: Miocene planktonic foraminiferal biogeography and paleoceanographic development of the Indo-Pacific region. Mem. Geol. Soc. Amer. 163: 197-236.

Loutrt, T.S., KennetT, J. P. \& Savin, S.M. 1983: Miocene equatorial and southwest Pacific paleoceanography from stable isotope evidence. Mar. Micropaleont. 8: 215-233.

LudBrook, N.H. \& Lindsay, J.M., 1969: Tertiary foraminiferal zones in South Australia. In Bronnimann, P. \& Renz, H. H. (Eds.) PROC. FIRST INTERNAT. CONF. PLANKTONIC MICROFOSSILS, GENEVA. Brill, Leiden 1: 366-374

McGowRAn, B., 1979: The Terriary of Australia: foraminiferal overview. Mar. Micropaleontol. 4: 235-264.

McGowran, B. \& Lr, Q., 1993: Miocene planktonic foraminifera from Lakes Entrance in Gippsland: midlatitude neritic signal from a transforming ocean. Mem. Assoc. Australas. Palaeont. 15: 395-405.

Quicy, P.G., 1970: Triangulina, n. gen. (Problematica) from the Tertiary of southern Australia. Micropaleontology 16: $179-184$.

Quilty, P.G., 1972: The biostratigraphy of the Tasmanian marine Tertiary. Pap. Proc. R. Soc. Tasm. 106: 25-44.

Quilty, P.G., 1974: Tasmanian Tertiary foraminifera. Part 1. Textulariina, Miliolina, Nodosariacea. Pap. Proc. R. Soc. Tasm. 108: 31-106.

Quilty, P.G., 1977a: Tasmanian Tertiary foraminifera. Part 2. Spirilinacea to Glabratellidae. Pap. Proc. R. Soc. Tasm. 111: 69-109.
Quntry, P.G., 1977b: Cenozoic sedimentation cycles in Western Auscralia. Geolooy 5: 336-340.

Qun.tY, P.G., 1980a: New rotalid foraminiferids from the OligoMiocene of Tasmania. Alcheringa 4: 299-311.

QuinY, P.G., 1980b: Sedimentation cycles in the Cretaceous and Cenozoic of Western Australia. Tectonophysics 63: 349-366.

QuiliY, P.G., 1982: Tasmanian Tertiary foraminifera. Part 3. Discorbacea (Eponididae) to Nonionacea. Pap. Proc. $R$. Soc. Tasm. 116: 5-51.

Qun' Y, P.G., 1985a: A Pliocene foraminiferid fauna from Flinders Island, Bass Strait. Pap. Proc. R. Soc. Tasm. 119: 89-91.

Qutity, P.G., 1985b: Miocene and Pliocene sediments dredged from the sea floor off St Helens, norcheastern Tasmania. Pap. Proc. R. Soc. Tasm. 119: 93-101.

Quil.T, P.G., 1993: Tasmantid and Lord Howe seamount chains: biostrarigraphy and palaeoceanographic significance. Alcheringa 17: 27-53.

RAO, C.P. \& Alabi3, M.H., 1992: Carbonare minerals, major and minor elements and oxygen and carbon isotopes and their variation with water depth in cool, temperate carbonates, western Tasmania, Australia. Mar. Geol. 103: $249-272$.

Stainforth, R.M., Lamb, J.L., Luterbacher, H., Beard, J.H. \& JePFORDS, R.M., 1975: Cenozoic planktonic foraminiferal zonation and characteristics of index forms. Univ. Kansas, Paleont. Contr. Art. 62: 1-425.

Sutheriano, F.L. \& Whiman, P., 1986: Potassium-argon ages of Tertiary volcanic rocks, Tasmania. Pap. Proc, $R$. Soc. Tasm. 120:77-86.

Vail, P.R., Mitchum, R.M., Jr, Todi, R.G., Widmiler, J.M., Thompson, S., III, Sangree, J.B., Bubb, J.N. \& Hati.elid, W.G., 1977: Seismic stratigraphy and global changes of sea level. In Payton, C. E. (Ed.): SEISMIC STRATIGRAPHY: APPLICATIONS TO HYDROCARBON EXPLORATION. Am. Assoc. Pet. Geol., Tulsa, Memoir 26: $49-212$.

Veevers, J.J. (Ed.) 1984: PHANEROZOIC EARTH HISTORY OF AUSTRALIA. Clarendon Press, Oxford.

Veevers, J.J., Powel., C.McA. \& Roots, S.R., 1991: Review of seafloor spreading around Australia. I. Synthesis of the patterns of spreading. Aust. J. Earth Sci. 38: 373-389.

VAN Morkhovfen, F.P.C.M., BergGreN, W.A. \& EDWARIS, A.S., 1986: CENOZOIC COSMOPOLITAN DEEPWATER BENTHIC FORAMINIFERA. Bull. Cent. Rech. Explor. Prod. Elf Aquitaine Mem. 11.

WALTON, W.R., 1964: Recent foraminiferal ecology and paleoecology. In Imbrie, J. \& Newell, N. (Eds.) APPROACHES TO PALEOECOLOGY. Wiley, New York: 151-237.

$$
\text { (accepted } 16 \text { February 1994) }
$$

